\title{
Effects of potassium deficiency on growth and protein synthesis in skeletal muscle and the heart of rats
}

\author{
BY INGE DØRUP AND TORBEN CLAUSEN* \\ Institute of Physiology, University of Aarhus, DK-8000 Aarhus C, Denmark
}

(Received 30 December 1988 - Accepted 20 February 1989)

\begin{abstract}
The effects of potassium deficiency on growth, $K$ content and protein synthesis have been compared in 4-13-week-old rats. When maintained on $\mathrm{K}$-deficient fodder $(1 \mathrm{mmol} / \mathrm{kg})$ rats ceased to grow within a few days, and the incorporation of $\left[{ }^{3} \mathrm{H}\right]$ leucine into skeletal muscle protein in vivo was reduced by 28-38\%. Pair-feeding experiments showed that this inhibition was not due to reduced energy intake. Following $14 \mathrm{~d}$ on K-deficient fodder, there was a further reduction (39-56\%) in the incorporation of ${ }^{3} \mathrm{H} \mid$ leucine into skeletal muscle protein, whereas the incorporation into plasma, heart and liver proteins was not affected. The accumulation of the non-metabolized amino acid $\alpha$-aminoisobutyric acid in the heart and skeletal muscles was not reduced. The inhibitory effect of $K$ deficiency on ${ }^{3} \mathrm{H}$-labelling of muscle protein was seen following intraperitoneal (10-240 $\mathrm{min}$ ) as well as intravenous (10 min) injection of $\left[{ }^{3} \mathrm{H} \mid\right.$ leucine. In addition, the incorporation of $\left[{ }^{3} \mathrm{H}\right]$ phenylalanine into skeletal muscle protein was reduced in $\mathrm{K}$-depleted animals. Following acute $\mathrm{K}$ repletion in vivo leading to complete normalization of muscle $K$ content, the incorporation of $\left.\right|^{3} \mathrm{H} \mid$ leucine into muscle protein showed no increase within $2 \mathrm{~h}$, but reached 76 and $104 \%$ of the control level within 24 and $72 \mathrm{~h}$ respectively. This was associated with a rapid initial weight gain, but normal body-weight was not reached until after 7 weeks of $K$ repletion. Following $7 \mathrm{~d}$ on K-deficient fodder the inhibition of growth and protein synthesis was closely correlated with the $K$ content of the fodder $(1-40 \mathrm{mmol} / \mathrm{kg})$ and significant already at modest reductions in muscle $K$ content. In vitro experiments with soleus muscle showed a linear relationship between the incorporation of $\left[{ }^{3} \mathrm{H}\right]$ leucine into muscle protein and $\mathrm{K}$ content, but the sensitivity to cellular $\mathrm{K}$ deficiency induced in vitro was much less pronounced than that induced in vivo. Thus, in soleus and extensor digitorum longus (EDL) muscles prepared from $\mathrm{K}$-deficient rats, the incorporation of ${ }^{3} \mathrm{H} \mid \mathrm{leucine}$ was reduced by 30 and $47 \%$ respectively. This defect was completely restored by $24 \mathrm{~h} \mathrm{~K}$ repletion in vivo. It is concluded that in the intact organism protein synthesis and growth are very sensitive to dietary $K$ deficiency and that this can only partly be accounted for by the reduction in cellular $K$ content per se. The observations emphasize the need for adequate $K$ supplies to ensure optimum utilization of food elements for protein synthesis and growth.
\end{abstract}

Growth: Potassium deficiency: Protein synthesis: Rat

It is well established that potassium deficiency interferes with growth in young animals (Cannon et al. 1952) as well as in children (Alleyne, 1970; Waterlow, 1984). This has been related to inhibition of the synthesis of proteins, a process which depends on $\mathrm{K}$ both in intact cells (Ledbetter \& Lubin, 1977) and in cell-free systems (Alexis et al. 1971). In one study, dietary $\mathrm{K}$ deficiency was found to cause a considerable decrease in the in vivo incorporation of $\left[{ }^{14} \mathrm{C}\right]$ leucine into muscle protein of growing chickens (Rinehart et al. 1967). In the mature rat, only $21 \%$ inhibition of $\left[{ }^{14} \mathrm{C}\right]$ leucine incorporation (not significant) could be detected following $35 \mathrm{~d}$ on K-deficient fodder (Gustafson et al. 1973). Little is known, however, about the effects of $\mathrm{K}$ deficiency on protein synthesis in young growing rats.

Protein synthesis is essential for growth and the restoration of tissue integrity during disease or malnutrition. Therefore, it is of interest to know by how much dietary and

* For reprints. 
intracellular $\mathrm{K}$ may be reduced before interference with protein synthesis and growth can be detected, which tissues are primarily affected, and how recovery may be induced by $\mathrm{K}$ supplementation. The present study explores these questions by comparing changes in tissue $\mathrm{K}$ contents and weight gain in young rats with the incorporation of $\left[{ }^{3} \mathrm{H}\right]$ leucine into muscle proteins in vivo and in vitro.

\section{MATERIALS AND METHODS}

\section{Animals and treatment}

All experiments were performed using female Wistar rats in the age range 4-13 weeks. The animals had free access to water, standard fodder or special diets and were kept at constant temperature $\left(23^{\circ}\right)$, humidity $(53 \%)$ and day length $(12 \mathrm{~h})$.

$\mathrm{K}$ deficiency was induced by maintaining 4-week-old rats on distilled water and special diets containing between 1 and $40 \mathrm{mmol} \mathrm{K} / \mathrm{kg}$. Age-matched control rats were maintained on standard fodder containing $260 \mathrm{mmol} \mathrm{K} / \mathrm{kg}$. Metal frames were positioned in the bottom of the cages to prevent the animals from having access to urine or faeces.

In some experiments, the animals were pair-fed by maintaining the controls on the same amount of fodder per $\mathrm{d}$ as the rats on K-deficient fodder. The daily food supply was established each morning after assessment (by weighing uneaten fodder) of the food consumed by the K-depleted group during the previous $24 \mathrm{~h}$. The pair-fed animals were then each given the same amount of fodder as a percentage of body-weight, as that consumed in the K-depleted group. A third group was given free access to fodder. All three groups received $\mathrm{K}$-deficient fodder $(1 \mathrm{mmol} \mathrm{K} / \mathrm{kg}$ fodder $)$ and, whereas the $\mathrm{K}$-depleted group received distilled water, pair-fed and ad lib.-fed animals were given a potassium chloride solution ( $250 \mathrm{mmol} / 1)$.

$\mathrm{K}$ repletion was performed after $\mathrm{K}$ depletion by the administration of a single dose of $\mathrm{KCl}(36 \mathrm{mmol} / \mathrm{kg}$ body-weight) via stomach tube and giving the animals free access to normal fodder. In other instances, the $\mathrm{K}$-depleted animals were $\mathrm{K}$-repleted simply by giving free access to normal fodder.

\section{In vivo experiments}

In most of the experiments, the incorporation of $\left[{ }^{3} \mathrm{H}\right]$ leucine into tissue proteins was determined using a modification of a previously developed technique (Young et al. 1975). Each animal was given an intraperitoneal injection of $10 \mathrm{ml} / \mathrm{kg}$ body-weight of a sodium chloride solution $(154 \mathrm{mmol} / \mathrm{l})$ containing $\left[{ }^{3} \mathrm{H}\right]$ leucine $(5 \mu \mathrm{Ci} / 1$ or $20 \mu \mathrm{Ci} / \mathrm{l})$ together with carrier L-leucine at a final concentration of $10 \mathrm{mmol} / 1$. At the indicated intervals of time after the injection ( 10 min $4 \mathrm{~h}$ ), the animals were killed by decapitation, blood samples withdrawn, and tissue samples weighing about $15-40 \mathrm{mg}$ (wet weight) rapidly excised and immediately frozen in liquid nitrogen. The frozen samples were weighed and placed in tubes containing ice-cold trichloroacetic acid (TCA) at a concentration of $300 \mathrm{mmol} / \mathrm{l}$. The tissue samples were homogenized using an Ultra-Turrax Tissue homogenizer (model TD 18/10). After centrifugation at $2000 \mathrm{rev} . / \mathrm{min}$, samples of the supernatant fraction were taken for determination of $\mathrm{K}$. The remaining supernatant fraction was discarded, and the protein sediment washed in $4 \mathrm{ml}$ TCA $(300 \mathrm{mmol} / \mathrm{l})$. In order to facilitate the removal of $\left[{ }^{3} \mathrm{H}\right]$ leucine, the TCA contained carrier L-leucine at a final concentration of $0.1 \mathrm{mmol} / \mathrm{l}$. After recentrifugation, the supernatant fraction was discarded and the protein sediment dissolved by heating for $1 \mathrm{~h}$ at $55^{\circ}$ with $1 \mathrm{ml}$ sodium hydroxide $(1 \mathrm{~mol} / \mathrm{l})$. After titration to neutrality with hydrochloric acid $(10 \mathrm{~mol} / 1)$, the dissolved proteins were transferred into counting vials containing $10 \mathrm{ml}$ of a toluene-triton $\mathrm{X}-114$ scintillation mixture. In some 
experiments, the protein content of the $\mathrm{NaOH}$-solubilized sediment was determined (Lowry et al. 1951).

For isolation of plasma proteins, heparinized blood samples were centrifuged and $100 \mu 1$ samples of the plasma mixed with $1 \mathrm{ml} \mathrm{TCA}(300 \mathrm{mmol} / \mathrm{l})$ and centrifuged. Samples of supernatant fraction were counted and the protein sediment was washed twice in $4 \mathrm{ml}$ TCA $(300 \mathrm{mmol} / \mathrm{l}$ ) containing $0 \cdot 1 \mathrm{mmol}$ carrier leucine $/ 1$. Finally, the sediment was dissolved in $\mathrm{NaOH}$, as for muscle protein, and radioactivity counted. Within each experiment, the volume and composition of the samples added to the counting vials were adjusted so as to give the same counting efficiency (around $25 \%$ ) for plasma, proteins and solutions used for injection.

The incorporation of ${ }^{3} \mathrm{H}$ activity label into total protein was expressed as counts/min (cpm) per g tissue wet weight or per ml plasma. Measurements performed 5 and $10 \mathrm{~min}$ after the injection of $\left[{ }^{3} \mathrm{H}\right]$ leucine showed that the incorporation of ${ }^{3} \mathrm{H}$ activity into muscle protein increased at a linear rate for $10 \mathrm{~min}$. In each experiment, a group of age-matched control rats were injected with the same volume of $\left[{ }^{3} \mathrm{H}\right]$ leucine solution $/ \mathrm{kg}$ body-weight.

The incorporation of $\left[{ }^{3} \mathrm{H}\right]$ amino acids into proteins was also measured following intravenous injection (McNurlan et al. 1979). Under phenobarbital anaesthesia, the saphenous vein was exposed. Each animal was given an intravenous injection of saline $(9 \mathrm{~g} \mathrm{NaCl} / 1 ; 10 \mathrm{ml} / \mathrm{kg}$ body-weight $)$ containing L-leucine $(100 \mathrm{mmol} / 1)$ and $\left[{ }^{3} \mathrm{H}\right]$ leucine $(200 \mu \mathrm{Ci} / \mathrm{kg}$ body-weight). In another experiment L-phenylalanine $(150 \mathrm{mmol} / \mathrm{l})$ and $\left[{ }^{3} \mathrm{H}\right]$ phenylalanine $(200 \mu \mathrm{Ci} / \mathrm{kg}$ body-weight) were injected intravenously. After $10 \mathrm{~min}$, the animals were killed by decapitation and the tissues and plasma processed for determination of ${ }^{3} \mathrm{H}$ activity in protein.

In some experiments, the accumulation of $\left[{ }^{14} \mathrm{C}\right] \alpha$-aminoisobutyric acid in the heart and skeletal muscles was measured. Each animal was given an intraperitoneal injection of $1 \mathrm{ml}$ $\mathrm{NaCl}(154 \mathrm{mmol} / \mathrm{l})$ containing $\left[{ }^{14} \mathrm{C}\right] \alpha$-aminoisobutyric acid $(2 \mu \mathrm{Ci} / \mathrm{ml})$. After 60 and $120 \mathrm{~min}$, tissue samples were prepared and homogenized in TCA $(300 \mathrm{mmol} / \mathrm{l})$. After centrifugation, the ${ }^{14} \mathrm{C}$ activity of the supernatant fraction was measured and expressed as cpm per $g$ tissue wet weight. The ${ }^{14} \mathrm{C}$-counting efficiency was around $80 \%$.

\section{In vitro experiments}

For the determination of $\left[{ }^{3} \mathrm{H}\right]$ leucine incorporation in vitro, intact soleus or extensor digitorum longus (EDL) muscles from animals weighing $60-70 \mathrm{~g}$ were washed and incubated in Krebs-Ringer bicarbonate buffer. The procedures for preparation of these muscles have previously been described (Kohn \& Clausen, 1971; Chinet et al. 1977). In order to reduce oxygen consumption and ensure viability, all incubations took place at $30^{\circ}$ under continuous gassing with a mixture of $95 \% \mathrm{O}_{2}$ and $5 \% \mathrm{CO}_{2}$. In order to vary the intracellular $\mathrm{K}$ concentration, muscles were pre-incubated in the presence of ouabain ( $1 \mathrm{mmol} / \mathrm{l})$ for $30-180 \mathrm{~min}$. Then the muscles were incubated in buffer containing $\left[{ }^{3} \mathrm{H}\right]$ leucine $(0.4 \mu \mathrm{Ci} / \mathrm{ml}, 0.5 \mathrm{mmol} / \mathrm{l})$. After incubation, the muscles were blotted, weighed and placed in tubes containing $2 \mathrm{ml}$ ice-cold TCA ( $300 \mathrm{mmol} / \mathrm{l})$. Muscles were then homogenized and, after centrifugation, the $\mathrm{K}$ content of the supernatant fraction and the ${ }^{3} \mathrm{H}$ activity of the protein sediment were determined using the methods described previously for in vivo experiments.

The incorporation of $\left[{ }^{3} \mathrm{H}\right]$ leucine into protein was also measured in soleus and EDL muscles prepared from rats which had been K-depleted for 1 week or K-depleted for 1 week and then K-repleted for $24 \mathrm{~h}$. 


\section{$K$ contents and serum proteins}

As in previous studies (Clausen \& Kohn, 1977) the $\mathrm{K}$ content of muscle tissue was determined by flame photometry of TCA extracts using a Radiometer FLM 3 flame photometer with lithium as internal standard. Plasma samples were taken for measurements of total protein and for separation of proteins by cellulose-acetate membrane electrophoresis at $\mathrm{pH} 8 \cdot 6$.

Amino acid analyses were performed directly on diluted plasma using Amino Quant (Hewlet-Packard).

\section{Diets, chemicals and isotopes}

All chemicals were of analytical grade. Ouabain, puromycin and cycloheximide were obtained from the Sigma Co., St Louis, MO, USA; L- $\left[4,5-{ }^{3} \mathrm{H}\right]$ leucine $(60 \mathrm{mCi} / \mu \mathrm{mol})$ and 2-amino- $\left[1-{ }^{14} \mathrm{C}\right]$ isobutyric acid $(60 \mathrm{mCi} / \mathrm{mmol})$ were obtained from Amersham International plc, Amersham, Bucks. Standard fodder as well as $\mathrm{K}$-deficient fodder (containing $1 \mathrm{mmol} \mathrm{K} / \mathrm{kg}$ ) were obtained from the Altromin Co., Lage, West Germany.

\section{Statistics}

All results are given as mean values with their standard errors. The significance of difference was assessed by the two-tailed $t$ test for groups of non-paired observations and by one-way analysis of variance. Linear correlation analysis of unweighted values was performed by the method of least squares.

\section{RESULTS}

\section{Growth retardation}

Fig. 1 shows the effects of $\mathrm{K}$-deficient fodder on growth in the age range $4-8$ weeks. It is evident that after $3 \mathrm{~d}$ on $\mathrm{K}$-deficient fodder (containing $1 \mathrm{mmol} / \mathrm{kg}$ ) growth is already significantly reduced, and after $14 \mathrm{~d}$, weight gain amounts to only $10 \%$ of that of the controls. Pair-feeding experiments showed that this could not be attributed to reduced intake of fodder (see p. 279). In contrast, animals which had been K-depleted for $14 \mathrm{~d}$ and then $\mathrm{K}$-repleted by the administration of $\mathrm{KCl}$ via a gastric tube, showed a $57 \%$ higher growth rate than the controls within the first week. In another experiment $14 \mathrm{~d}$ of $\mathrm{K}$ depletion even gave a small weight loss. $\mathrm{K}$-depleted animals which in this experiment were $\mathrm{K}$-repleted by giving free access to normal fodder, showed a $108 \%$ higher growth rate than the controls within the first week. During the following weeks, however, the growth rate declined, and the K-depleted and K-repleted rats did not reach the same body-weight as the controls until 5-7 weeks after $\mathrm{K}$ repletion had started.

\section{In vitro experiments}

The incorporation of $\left[{ }^{3} \mathrm{H}\right]$ leucine into muscle protein was examined using substances blocking protein synthesis. In the isolated soleus muscle obtained from 4-week-old rats, the incorporation of $\left[{ }^{3} \mathrm{H}\right]$ leucine into protein was inhibited by $87 \%$ in the presence of puromycin $(100 \mu \mathrm{g} / \mathrm{ml})$ and by $95 \%$ in the presence of cycloheximide $(10 \mu \mathrm{g} / \mathrm{ml})$.

In order to determine by how much cellular $\mathrm{K}$ content had to be reduced before the incorporation of $\left[{ }^{3} \mathrm{H}\right]$ leucine into protein was impaired, soleus muscles were $\mathrm{K}$-depleted to varying extents by pre-incubation with ouabain $(1 \mathrm{mmol} / \mathrm{l})$ for $30-180 \mathrm{~min}$. As shown in Fig. 2, this gave muscles with $\mathrm{K}$ contents varying from 16 to $74 \mu \mathrm{mol} / \mathrm{g}$ wet weight (including the controls not exposed to ouabain). Over this range, the incorporation of $\left[{ }^{3} \mathrm{H}\right]$ leucine into protein was reduced in proportion to the decrease in $\mathrm{K}$ content, and a highly significant correlation could be established $(r 0.86 ; P<0.001)$. 


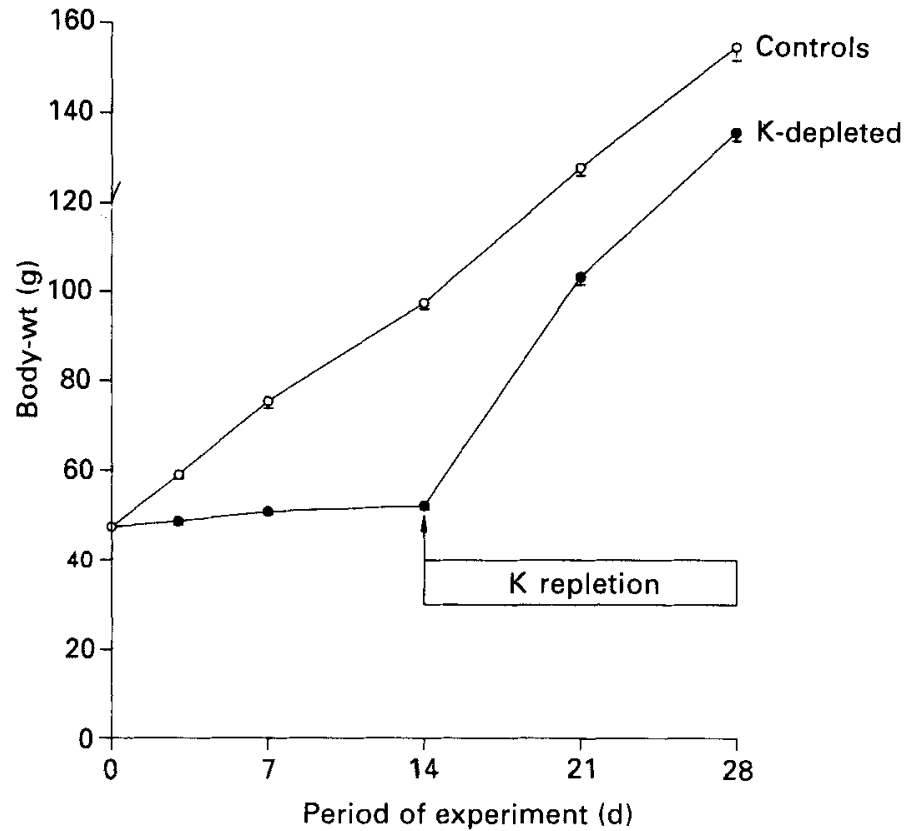

Fig. 1. Effect of potassium depletion and $\mathbf{K}$ repletion on body-weight gain. Groups of 4-week-old rats were maintained on standard fodder or K-deficient fodder. After 2 weeks, the rats on K-deficient fodder were $\mathrm{K}$ repleted by the administration of potassium chloride via.gastric tube ( $36 \mathrm{mmol} / \mathrm{kg}$ body-weight). Henceforth, both groups of animals were maintained on the $\mathrm{K}$-deficient fodder (Altromin) enriched with $\mathrm{KCl}$ so as to contain the same amount of $\mathrm{K}$ as the standard fodder $(260 \mathrm{mmol} / \mathrm{kg})$. Points are the mean weights of six to eighteen animals, with their standard errors represented by vertical bars. The difference between the body-weight of the controls and that of the $\mathrm{K}$-depleted or repleted rats was significant at all points $(P<0 \cdot 001)$

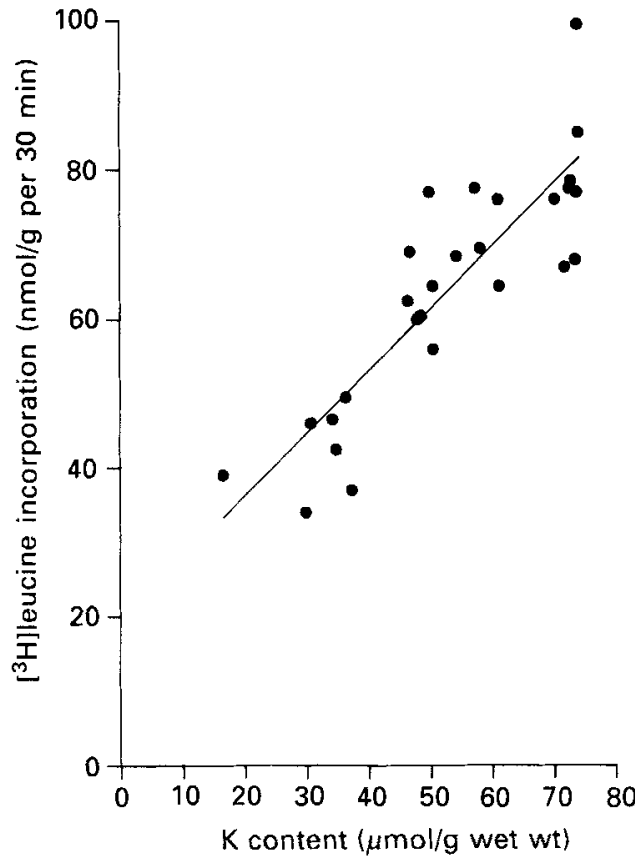

Fig. 2. The potassium content and $\left[{ }^{3} \mathrm{H}\right]$ leucine incorporation into protein of soleus muscle following $\mathrm{K}$ depletion in vitro. Soleus muscles were $\mathrm{K}$-depleted by pre-exposure to ouabain $(1 \mathrm{mmol} / \mathrm{l})$ for $30-180 \mathrm{~min}$ and then incubated for $30 \mathrm{~min}$ in buffer containing $\left[{ }^{3} \mathrm{H}\right]$ leucine. Each point represents one soleus muscle, and the rate of incorporation of ${ }^{3} \mathrm{H}$ activity is expressed as nmol $/ \mathrm{g}$ wet weight per $30 \mathrm{~min}$. The correlation line was constructed using the method of least squares. $r 0.86, P<0.001$. 
Table 1. Effect of 1 week of potassium depletion or repletion on the in vitro incorporation of $\left[{ }^{3}\right.$ H]leucine into muscle protein $\dagger$

(Values are means and standard errors for four to eight muscles)

\begin{tabular}{|c|c|c|c|c|c|c|}
\hline \multirow[b]{3}{*}{ Muscle } & \multicolumn{6}{|c|}{$\left[{ }^{3} \mathrm{H}\right]$ leucine incorporation $(\mathrm{nmol} / \mathrm{g}$ per $30 \mathrm{~min})$ into proteir } \\
\hline & \multicolumn{2}{|c|}{ Control } & \multicolumn{2}{|c|}{ K-depleted } & \multicolumn{2}{|c|}{ K-depleted/repleted } \\
\hline & Mean & SE & Mean & $\mathrm{SE}$ & Mean & $\mathrm{SE}$ \\
\hline Soleus & 81.9 & 1.7 & $57 \cdot 6^{* * *}$ & 4.9 & $91.9 * *$ & $1 \cdot 1$ \\
\hline Extensor digitorum longus & $56 \cdot 3$ & 1.9 & $30 \cdot 0^{* * *}$ & 1.6 & $55 \cdot 4$ & $2 \cdot 1$ \\
\hline
\end{tabular}

Significantly different from control values: $* * P<0 \cdot 01, * * * P<0.001$.

$\dagger$ Rats (4 weeks old) were maintained for 1 week on K-deficient fodder (K-depleted) or on the same fodder enriched with potassium chloride to a final concentration of $260 \mathrm{mmol} / \mathrm{kg}$ (controls). The third group was $\mathrm{K}$-depleted for 1 week and then K-repleted by giving free access to the K-enriched fodder for $24 \mathrm{~h}$ (K-depleted/repleted). Soleus and extensor digitorum longus muscles were prepared and incubated for $30 \mathrm{~min}$ in buffer containing $\left[{ }^{3} \mathrm{H}\right]$ leucine.

In order to determine whether the exposure to $\mathrm{K}$-depletion in vivo would cause an impairment of protein synthesis which could be detected in vitro, the incorporation of $\left[{ }^{3} \mathrm{H}\right]$ leucine into protein was measured in soleus and EDL muscles obtained from rats which had been K-depleted for 1 week, or K-depleted for 1 week and then K-repleted for $24 \mathrm{~h}$. It should be noted that in the soleus and EDL muscles prepared from 1-week K-depleted animals, the K-content following the incubation was reduced by 10 and $11 \%$ respectively compared with age-matched controls. In spite of this relatively modest decrease, the incorporation of $\left[{ }^{3} \mathrm{H}\right]$ leucine into protein was inhibited by 30 and $47 \%$ in soleus and EDL respectively (Table 1). This impairment of protein synthesis could be restored by giving the animals access to fodder with normal K-content for $24 \mathrm{~h}$ before the muscles were prepared (Table 1).

\section{In vivo experiments}

The effect of $\mathrm{K}$-deficiency on $\left[{ }^{3} \mathrm{H}\right]$ leucine incorporation into proteins in vivo was assessed using two routes of administration. Table 2 shows the ${ }^{3} \mathrm{H}$ activity in skeletal muscles $10 \mathrm{~min}$ after intravenous or intraperitoneal injection of the same quantity of $\left[{ }^{3} \mathrm{H}\right]$ leucine $(200 \mu \mathrm{Ci} / \mathrm{kg}$ body-weight). Generally, the intravenous administration gave somewhat lower and more uniform ${ }^{3} \mathrm{H}$ levels in all the tissues tested than the intraperitoneal administration. This is probably caused by the difference in specific radioactivity in the injections $(2 \mu \mathrm{Ci} / \mu \mathrm{mol} v \cdot 0 \cdot 2 \mu \mathrm{Ci} / \mu \mathrm{mol})$. In the experiments with intraperitoneal injection, the ${ }^{3} \mathrm{H}$ activity of diaphragm protein was higher than that of the other muscles, presumably because the $\left[{ }^{3} \mathrm{H}\right]$ leucine had more ready access to this muscle. Both types of experiments showed, however, the same trend, namely that in the K-deficient animals, the incorporation of ${ }^{3} \mathrm{H}$ activity into protein was significantly reduced in skeletal muscle. Following intraperitoneal injection the incorporation of $\left[{ }^{3} \mathrm{H}\right]$ leucine in the $\mathrm{K}$-depleted animals into soleus, EDL and diaphragm muscles was reduced by 25,38 and $32 \%$ respectively (Table 2). This should be compared with the values obtained following intravenous injection, where $\mathrm{K}$-depletion was accompanied by a 24,38 and $28 \%$ reduction in the same three muscles respectively (Table 2). Both types of experiment cause a considerable rise in plasma leucine and there was no significant difference between the plasma ${ }^{3} \mathrm{H}$ activity level in controls and K-deficient animals. Therefore, the inhibitory effect of K-deficiency on $\left[{ }^{3} \mathrm{H}\right]$ leucine incorporation cannot be attributed to differences in specific activity. 


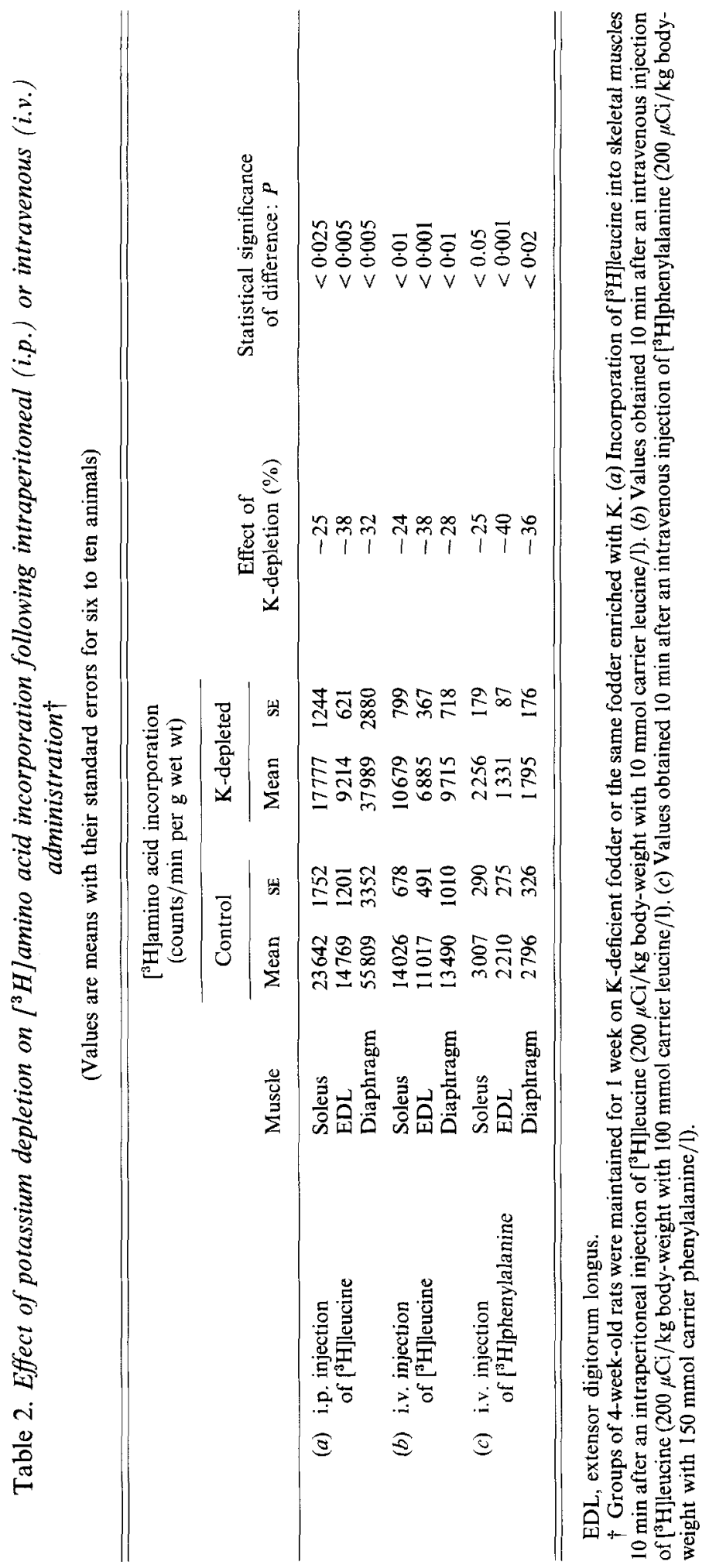


(a) Extensor digitorum longus muscle
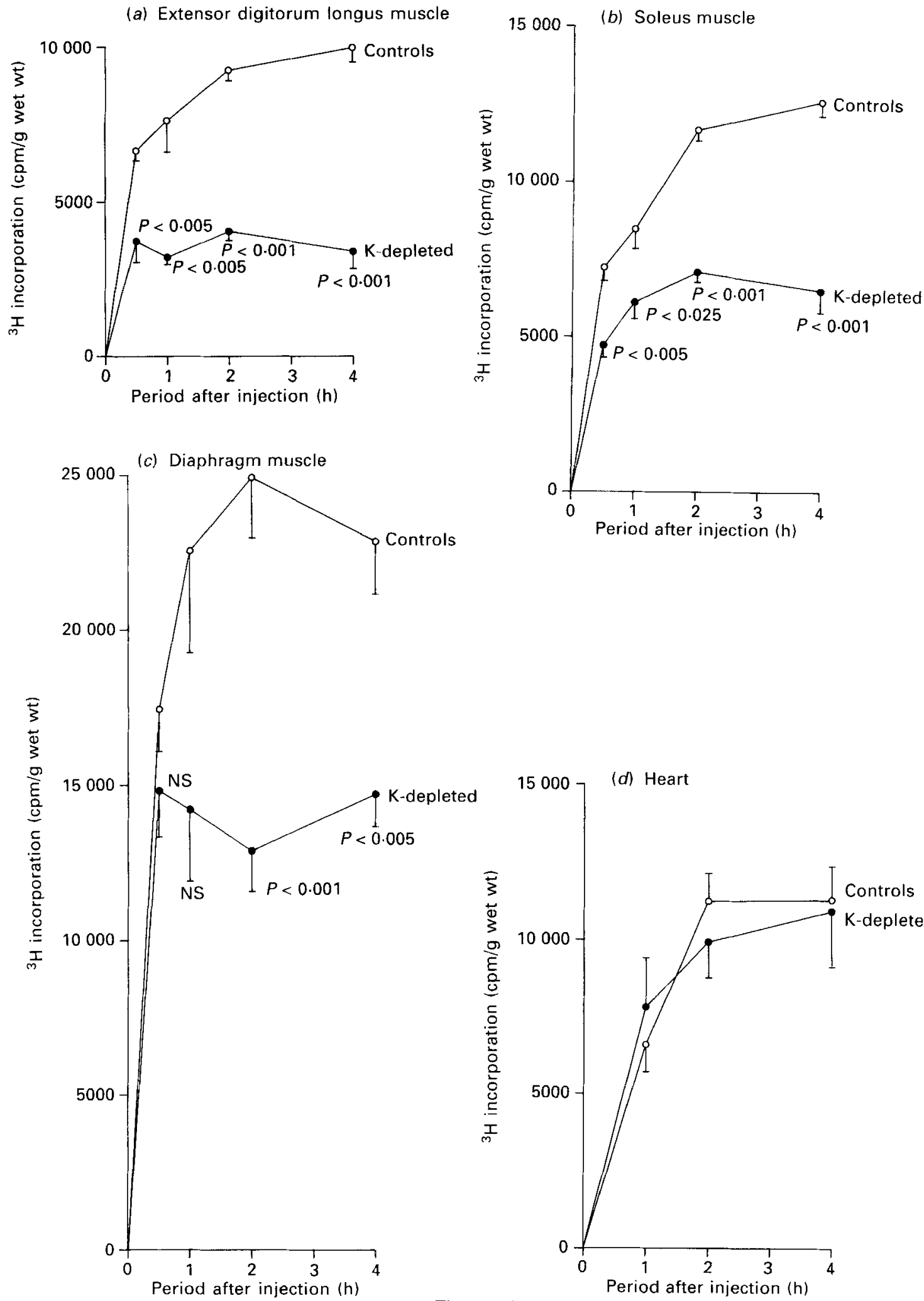

Fig. 3(a-d).

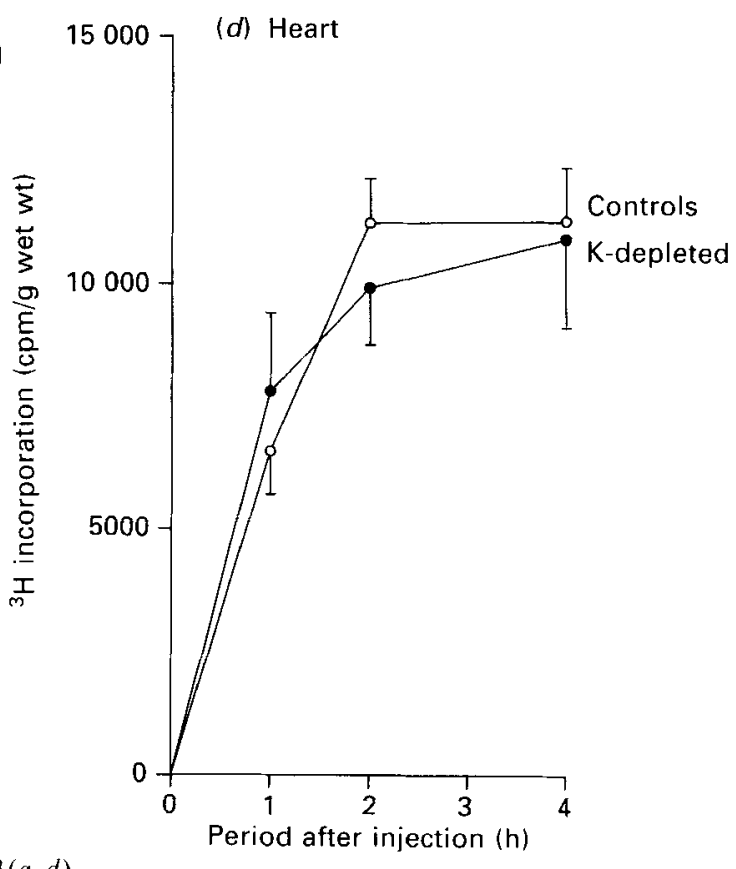


Furthermore, measurement of plasma leucine concentration before injection (167 $\mu \mathrm{M}$ (SE 14) in control v. $114 \mu \mathrm{M}$ (SE 9) in K-depleted animals $(n 6 / 6), P<0.02)$ indicates that differences in plasma leucine were not responsible for the inhibition of $\left[{ }^{3} \mathrm{H}\right]$ leucine incorporation seen in K-depleted animals. Finally, the incorporation of $\left[{ }^{3} \mathrm{H}\right]$ phenylalanine into protein was inhibited in K-depleted animals, confirming the general trend (Table 2).

The effect of $\mathrm{K}$ deficiency on the time-course of labelling was assessed in rats which had been given $\mathrm{K}$-deficient fodder $(1 \mathrm{mmol} / \mathrm{kg})$ for $14 \mathrm{~d}$. They were injected intraperitoneally with the same dose of $\left[{ }^{3} \mathrm{H}\right]$ leucine $(100 \mu \mathrm{mol}$ and $50 \mu \mathrm{Ci} / \mathrm{kg}$ body-weight), and it should be noted that at the various times of measurement, the TCA-soluble ${ }^{3} \mathrm{H}$ activity in plasma was not significantly different from that of the control rats. In spite of this, the ${ }^{3} \mathrm{H}$ activity of the total protein isolated from all the skeletal muscle samples was clearly reduced. Total muscle protein concentration $(\mathrm{mg} / \mathrm{g}$ wet weight), however, was not reduced in the $\mathrm{K}$ deficient animals.

Fig. 3( $a-d)$ shows the time-course of the incorporation of $\left[{ }^{3} \mathrm{H}\right]$ leucine into the proteins of various types of skeletal muscle and the heart. In all the tissues studied, the maximum incorporation level was reached in about $4 \mathrm{~h}$, followed by a relatively slow decline over the next $20 \mathrm{~h}$ (not shown). In the diaphragm muscle, the ${ }^{3} \mathrm{H}$ activity reached a level about twofold higher than that of the heart and hind-limb muscles, presumably because part of the $\left[{ }^{3} \mathrm{H}\right]$ leucine reached the muscle fibres by diffusion directly from the peritoneal cavity.

The most pronounced effect of K deficiency was seen in EDL. As shown in Fig. $3 a$, the inhibition varied from $44 \%$ within the first $30 \mathrm{~min}$ to $66 \%$ over $4 \mathrm{~h}$. In soleus (Fig. $3 \mathrm{~b}$ ), the inhibition varied between 28 and $49 \%$ over the first $4 \mathrm{~h}$, whereas in diaphragm (Fig. $3 c$ ) between 15 and $48 \%$ reduction was found. At variance with skeletal muscle, the heart ventricles showed no significant response to $\mathrm{K}$ deficiency (Fig. $3 d$ ). In the $\mathrm{K}$-deficient rats, the decrease in ${ }^{3} \mathrm{H}$ activity from 4 to $24 \mathrm{~h}$ in soleus, diaphragm and the heart was considerably slower than in the controls. This possibly reflects a reduced rate of protein degradation.

Since a $2-\mathrm{h}$ interval allowed the detection of a clear-cut response to $\mathrm{K}$ deficiency, this time-period was used in the following experiments which were designed to compare the changes in $\mathrm{K}$ content and incorporation of leucine into protein.

In the proteins isolated from the liver and plasma, ${ }^{3} \mathrm{H}$ activity was the same in controls and K-deficient rats. Total plasma proteins were 48.3 (SE 1.0) and 52.2 (SE 2.1) g/l in controls and K-deficient rats respectively. Only the $\alpha_{2}$-macroglobulin fraction showed a significant change with $\mathrm{K}$ depletion $(+107 \%)$.

Fig. 4( $a-b)$ shows the $\mathrm{K}$ content and the incorporation of $\left[{ }^{3} \mathrm{H}\right]$ leucine into proteins of soleus and EDL following various periods on $\mathrm{K}$-deficient fodder. After $3 \mathrm{~d}$, the $\mathrm{K}$ content and $\left[{ }^{3} \mathrm{H}\right] l$ leucine incoporation in EDL were reduced by 22 and $38 \%$ respectively. In soleus, reductions of 16 and $28 \%$ were found. During the folowing $11 \mathrm{~d}$, somewhat more pronounced reductions in $\mathrm{K}$ content and $\left[{ }^{3} \mathrm{H}\right]$ leucine incorporation into skeletal muscle were observed. Again, the heart showed no significant decrease in $\left[{ }^{3} \mathrm{H}\right]$ leucine incorporation, and its $\mathrm{K}$ content underwent a smaller reduction $(17 \%)$ than that of the EDL and soleus muscles ( 27 and $40 \%$ respectively).

Fig. $3(a-d)$. Effects of $\mathbf{K}$ depletion on the incorporation of ${ }^{3} \mathrm{H}$ activity from $\left[{ }^{3} \mathrm{H}\right]$ leucine into muscle protein. Groups of 4-week-old rats were either maintained on standard fodder or on $\mathrm{K}$-deficient fodder for 2 weeks and then given an intraperitoneal injection $(10 \mathrm{ml} / \mathrm{kg}$ body-weight) of a solution containing $154 \mathrm{mmol}$ sodium chloride/l, $10 \mathrm{mmol} \mathrm{L-leucine/1}$ and $5 \mu \mathrm{Ci}\left[{ }^{3} \mathrm{H}\right] \mathrm{L}$-leucine/ml. At the indicated time-intervals after the injection, the animals were decapitated and samples of the tissues indicated excised, frozen and prepared for the isolation and determination of ${ }^{3} \mathrm{H}$ in protein. The incorporation of ${ }^{3} \mathrm{H}$ is expressed as counts $/ \mathrm{min}(\mathrm{cpm})$ per g wet weight. Points are means of values obtained in six to twenty animals, with their standard errors represented by vertical bars. The significance of the difference between controls and experimental animals is indicated by $P$ except in Fig. $3 d$, where none of the differences reached statistical significance. NS, not significant. 

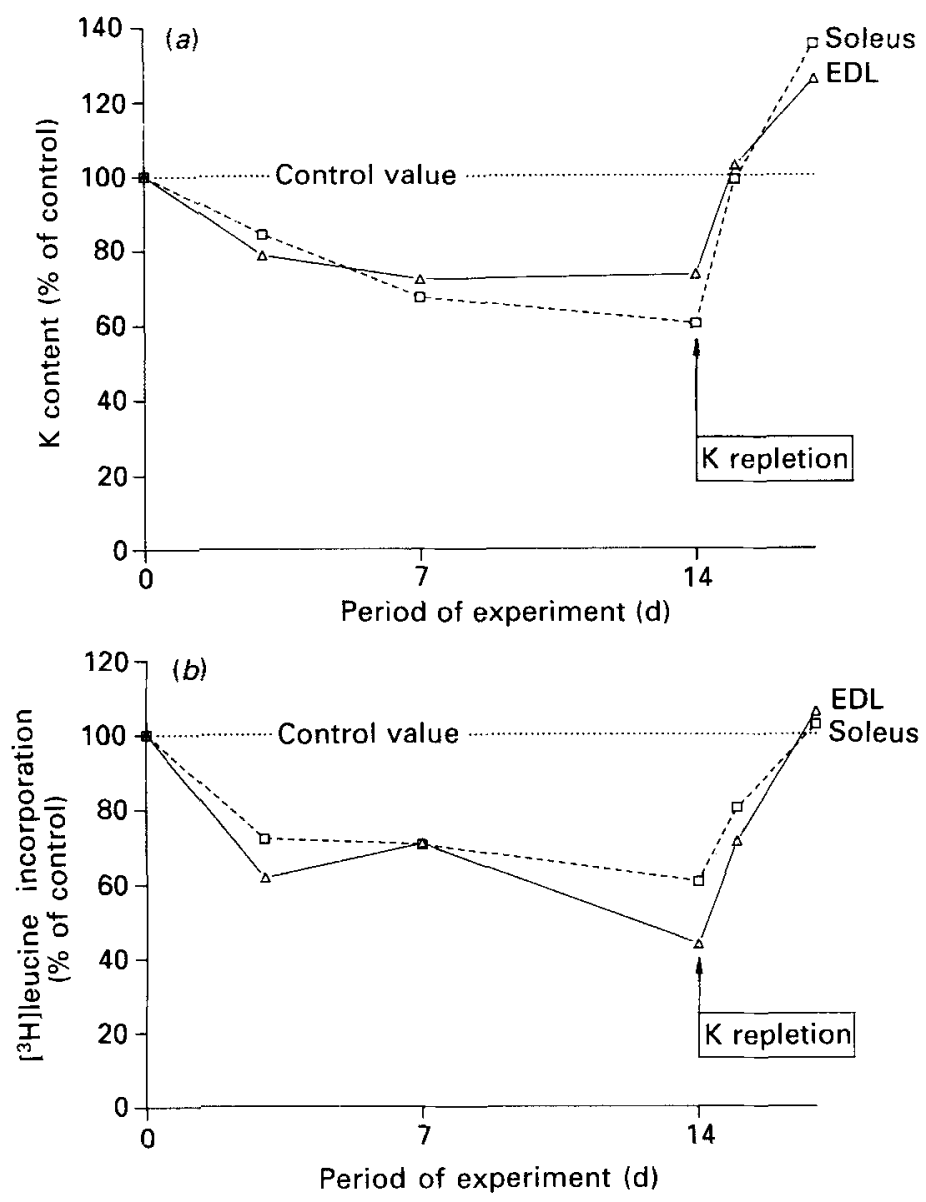

Fig. 4. Time-course of the changes $(a)$ in potassium content and $(b)$ the incorporation of ${ }^{3} \mathrm{H}$ from $\left[{ }^{3} \mathrm{H}\right]$ leucine into muscle protein during $\mathrm{K}$ depletion or repletion. Rats ( 4 weeks old) were maintained on standard fodder or on $\mathrm{K}$ deficient fodder for 2 weeks and then K-repleted (see p. 270). At the indicated time-intervals, each animal was given an intraperitoneal injection $(10 \mathrm{ml} / \mathrm{kg}$ body-weight) of a solution containing $154 \mathrm{mmol}$ sodium chloride/1, $10 \mathrm{mmol} \mathrm{L}$-leucine $/ 1$ and $5 \mu \mathrm{Ci}\left[{ }^{3} \mathrm{H}\right] \mathrm{L}$-leucine $/ \mathrm{ml}$. After $2 \mathrm{~h}$, the animals were decapitated and soleus and extensor digitorum longus (EDL) prepared for determination of $\mathrm{K}$ content and the incorporation of ${ }^{3} \mathrm{H}$ activity into protein. All values are given as a percentage of the control value determined using the age-matched rats on standard fodder. Points are means of values determined in five to twenty animals.

This would indicate that the inhibition of $\left[{ }^{3} \mathrm{H}\right]$ leucine incorporation was mainly related to the reduction in $\mathrm{K}$ content. If the impaired protein synthesis were entirely due to decreased intracellular $\mathrm{K}$, it should be possible to obtain complete normalization by restoring the normal $\mathrm{K}$ content. In rats which had been $\mathrm{K}$-depleted for $14 \mathrm{~d}$ and then $\mathrm{K}$ repleted by the administration of $\mathrm{KCl}$ via stomach tube, the $\mathrm{K}$ content of the soleus and EDL muscles reached values even slightly above the control level within $2 \mathrm{~h}$. In spite of this, the incorporation of $\left[{ }^{3} \mathrm{H}\right]$ leucine into the protein of soleus and EDL muscles was not significantly different from that measured in age-matched $14 \mathrm{~d} \mathrm{~K}$-depleted rats $(5834$ (SE 250) v. 6908 (SE 629) cpm/g in soleus and 4517 (SE 375) v. 4170 (SE 805) cpm/g in EDL, $n 6)$. Even $24 \mathrm{~h}$ after this $\mathrm{K}$ repletion, the incorporation of $\left[{ }^{3} \mathrm{H}\right]$ leucine into soleus and $\mathrm{EDL}$ was still suppressed by 20 and $29 \%$ respectively. At $72 \mathrm{~h}$ after the onset of $\mathrm{K}$ repletion, the incorporation of $\left[{ }^{3} \mathrm{H}\right]$ leucine reached a level slightly above the control value (Fig. $4 b$ ). Thus, 


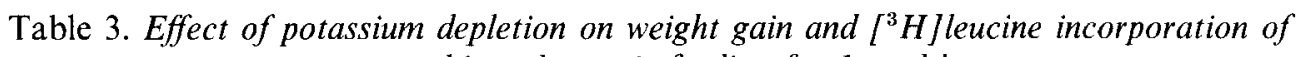
rats subjected to pair-feeding for 1 week

(Values are means and standard errors for six to twelve animals)

\begin{tabular}{|c|c|c|c|c|c|c|c|}
\hline & & \multicolumn{2}{|c|}{ Ad lib.-fed } & \multicolumn{2}{|c|}{ Pair-fed } & \multicolumn{2}{|c|}{ K-depleted } \\
\hline & & Mean & SE & Mean & $\mathrm{SE}$ & Mean & $\mathrm{SE}$ \\
\hline (a) & $\mathrm{Wt}$ gain $(\mathrm{g})$ & $27 \cdot 4$ & $0 \cdot 7$ & $25 \cdot 1^{*}$ & 0.5 & $4 \cdot 7+1+$ & $0 \cdot 6$ \\
\hline \multirow[t]{3}{*}{ (b) } & $\begin{array}{l}{\left[{ }^{3} \mathrm{H}\right] \text { leucine }} \\
\text { incorporation } \\
\text { (counts/min per } \mathrm{g} \text { wet } \mathrm{wt} \text { ) }\end{array}$ & & & & & & \\
\hline & Soleus muscle & 9141 & 582 & 8667 & 272 & $7023+1+$ & 266 \\
\hline & Extensor digitorum longus & 8756 & 779 & 8585 & 295 & $5069+\dagger \dagger$ & 455 \\
\hline
\end{tabular}

Significantly different from ad lib.-fed group: $* P<0 \cdot 05$.

Significantly different from pair-fed group: $\uparrow \dagger \uparrow P<0.001$.

$\ddagger$ Groups of 4-week-old rats were given free access to K-deficient fodder and distilled water (K-depleted) or Kdeficient fodder and potassium chloride $(250 \mathrm{mmol} / \mathrm{l}$ ) (ad lib.-fed controls). The third group was given the same amount of K-deficient fodder (relative to body-weight) as that consumed by the K-deficient group during the previous $24 \mathrm{~h}$ and given free access to $\mathrm{KCl}(250 \mathrm{mmol} / \mathrm{l})$ (pair-fed controls). (a) Weight gain in 1 week, $(b)$ incorporation of $\left[{ }^{3} \mathrm{H}\right]$ leucine into soleus and extensor digitorum longus muscles following intraperitonea! injection.

the impaired protein synthesis could not be attributed to the cellular $\mathrm{K}$ deficiency as such, but also seemed to depend on some other regulatory factor.

In order to examine the possibility that the effects of $\mathrm{K}$-deficient fodder might have been caused by other anomalies in composition than the lack of $K$, control experiments were performed using $\mathrm{K}$-deficient fodder in which the $\mathrm{K}$ content had been normalized (to $260 \mathrm{mmol} / \mathrm{kg}$ ) by the addition of $\mathrm{KCl}$. It was found that the weight gain of 3-week-old rats maintained on this fodder was $85 \%$ of that of rats on standard fodder, and the $\left[{ }^{3} \mathrm{H}\right]$ leucine incorporation into muscle protein showed no significant difference. After $\mathrm{K}$ depletion for 2 weeks, the administration of the K-enriched fodder gave the same weight gain and restoration of $\left[{ }^{3} \mathrm{H}\right]$ leucine incorporation as the standard fodder used for the control rats.

It could be envisaged that the administration of $\mathrm{K}$-deficient fodder would lead to reduced energy intake and ensuing impairment of growth and protein synthesis. As shown in Table 3 , however, pair-feeding only caused a modest $(10 \%)$ reduction in growth and no change in the incorporation of $\left[{ }^{3} \mathrm{H}\right]$ leucine into muscle protein compared with ad lib. feeding. The same experiment showed a considerable reduction in growth $(81 \%)$ and $\left[{ }^{3} \mathrm{H}\right]$ leucine incorporation (19-41\%) in the K-deficient animals compared with the pair-fed controls.

A more detailed analysis of the importance of muscle $\mathrm{K}$ content for growth and protein synthesis was performed by maintaining 4-week-old rats for 1 week on $\mathrm{K}$-deficient fodder which had been $\mathrm{K}$-enriched by the addition of graded amounts of $\mathrm{KCl}(1-260 \mathrm{mmol} / \mathrm{kg})$. As can be seen from Fig. 5, fodder containing 40 and $20 \mathrm{mmol} \mathrm{K} / \mathrm{kg}$ caused no significant change in the $\mathrm{K}$ content of soleus muscle, but significant reductions in body-weight gain of 15 and $26 \%$ respectively. In rats maintained on fodder containing $10 \mathrm{mmol} \mathrm{K} / \mathrm{kg}$ the $\mathrm{K}$ content of soleus was only reduced by $9 \%$, but the body-weight gain and $\left[{ }^{3} \mathrm{H}\right]$ leucine incorporation had dropped by 76 and $34 \%$ respectively.

Varying the $\mathrm{K}$ content of fodder from 40 to $1 \mathrm{mmol} \mathrm{K} / \mathrm{kg}$, body-weight gain was inhibited in proportion to the fodder $\mathrm{K}$ content, and a significant correlation could be established ( $r \quad 0.87, P<0.001$ ). Also the $\left[{ }^{3} \mathrm{H}\right]$ leucine incorporation was significantly correlated with the $\mathrm{K}$ content of fodder in the range $1-40 \mathrm{mmol} / \mathrm{kg}(r 0.78, P<0.001)$. 
(a)

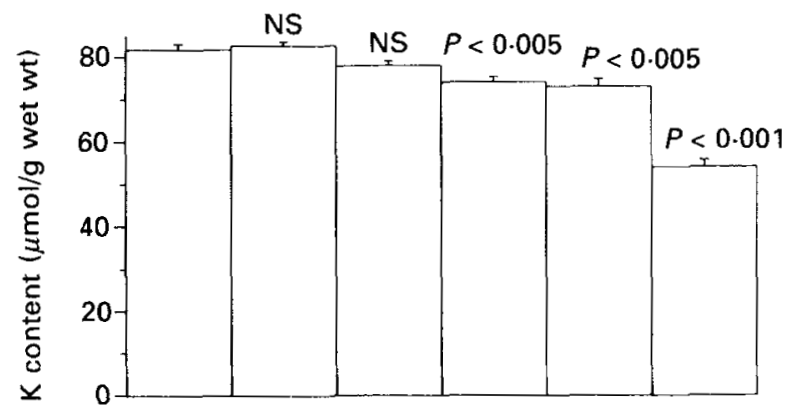

(b)

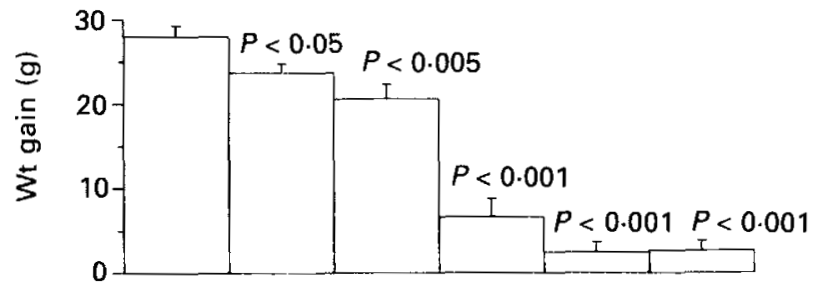

(c)

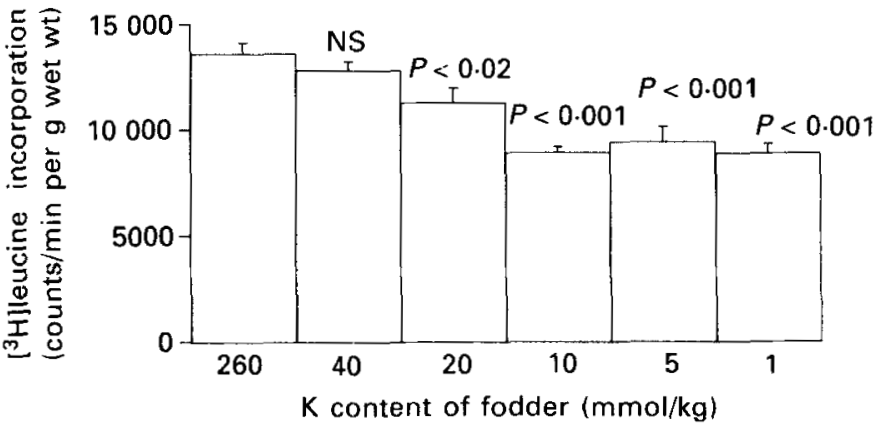

Fig. 5. Effects of graded potassium-deficient fodder on $(a) \mathrm{K}$ content, $(b)$ weight gain and $(c)$ incorporation of ${ }^{3} \mathrm{H}$ from $\left[{ }^{3} \mathrm{H}\right]$ leucine into soleus muscle protein. Rats (4 weeks old) were maintained for 1 week on K-deficient fodder which had been enriched by the addition of graded amounts of $\mathrm{KCl}$ to a final content of $1-260 \mathrm{mmol} / \mathrm{kg}$. Values are means of results obtained with six to twelve animals with their standard errors represented by vertical bars. Statistical significance levels for differences between controls (kept on fodder containing $260 \mathrm{mmol} \mathrm{K} / \mathrm{kg}$ ) and Kdepleted animals are expressed by $P$. NS, not significant.

Somewhat weaker correlations were obtained between muscle $K$ content and $\left[{ }^{3} \mathrm{H}\right]$ leucine incorportion $(r 0.64, P<0.001)$ as well as between muscle $\mathrm{K}$ content and growth $(r 0.71$, $P<0.001$ ).

The inhibitory effect of $\mathrm{K}$ depletion on leucine incorporation into protein might in part be attributed to a reduction in the intracellular accumulation via a sodium-gradientdependent transport mechanism. The significance of this transport process was assessed in experiments with $\alpha$-aminoisobutyric acid, a non-metabolized amino acid, which is accumulated in rat skeletal muscle via Na-dependent transport (Kipnis \& Parrish, 1965). Measurements performed in twenty-four rats (twelve which had been K-depleted for $14 \mathrm{~d}$ and twelve age-matched controls) showed that 60 or $120 \mathrm{~min}$ after intraperitoneal injection of $\left[{ }^{14} \mathrm{C}\right] \alpha$-aminoisobutyric acid, the ${ }^{14} \mathrm{C}$ activity accumulated in the heart ventricles, 
diaphragm, soleus and EDL was not significantly reduced in the K-deficient animals compared with the controls.

\section{DISCUSSION}

The present study was primarily undertaken with the purpose of obtaining quantitative information about the $\mathrm{K}$ requirement for growth and protein synthesis. A second aim was to develop a simple procedure allowing the detection of protein synthesis defects under in vivo conditions.

\section{Growth retardation}

The results confirm and extend earlier observations that dietary $\mathrm{K}$ is essential for optimal growth (Kornberg \& Endicott, 1946; Cannon et al. 1952; Sapir et al. 1976). This is perhaps most strikingly illustrated by the fact that already within the first $3 \mathrm{~d}$ on K-deficient fodder $(1 \mathrm{mmol} \mathrm{K} / \mathrm{kg}$ ), there was virtually no weight gain (Fig. 1). Furthermore, during the first week after $\mathrm{K}$ repletion, weight gain was between 57 and $108 \%$ above that for age-matched controls. In spite of this early growth acceleration, normal weight was not attained until 5-7 weeks after the return to control fodder. Thus, $\mathrm{K}$ deficiency seems to cause a serious set-back in growth, which is not readily compensated. It would be expected that this growth retardation was mainly the result of decreased intracellular $\mathrm{K}$ in the muscles. However, the experiments with moderately $\mathrm{K}$-deficient fodder $(40-20 \mathrm{mmol} / \mathrm{kg})$ indicate that growth is very sensitive to inadequate $\mathrm{K}$ supplies. Already at very modest reductions in muscle $\mathrm{K}$ $(0-5 \%)$, there was a highly significant inhibition of weight gain (15-26\%). All variables were, however, severely affected when the animals received fodder containing less than $20 \mathrm{mmol} \mathrm{K} / \mathrm{kg}$. This minimum dietary $\mathrm{K}$ level is in keeping with the studies of Kornberg \& Endicott (1946), who found a dietary $\mathrm{K}$ concentration of $1.7 \mathrm{~g} / \mathrm{kg}$ (about $40 \mathrm{mmol} / \mathrm{kg}$ ) to be the minimum for optimum growth.

As body-weight of the animals decreased during graded $\mathrm{K}$ depletion, the wet weight of the soleus and EDL muscles showed the same relative decrease, indicating that the inhibited growth of the animals can be accounted for largely by the reduced growth of the muscles.

Earlier studies have demonstrated immediate cessation of growth when $\mathrm{K}$ supply was insufficient, but this has been explained by a reduction in the intracellular concentration of K (Cannon et al. 1952; Alexis et al. 1971). To our knowledge it has not previously been demonstrated that even minute reductions in muscle $\mathrm{K}$ could be associated with growth retardation. Taken together, the very early and marked growth responses to alterations in dietary $\mathrm{K}$ supplies and the highly significant correlation between $\mathrm{K}$ content of fodder and weight gain indicate that regulatory factors other than cellular $\mathrm{K}$ are of importance in determining the rate of protein turnover and weight gain.

Recent studies performed in our laboratory demonstrated that in young rats, the administration of $\mathrm{K}$-deficient fodder leads to a decrease in the plasma levels of growth hormone and somatomedin C (Flyvbjerg et al. 1988). This reduction is related to the decrease in $\mathrm{K}$ content of the fodder and was shown to be fully reversible within $24 \mathrm{~h}$ of the return to standard fodder with normal K content (Flyvbjerg et al. 1988).

\section{In vitro experiments}

The rate of $\left[{ }^{3} \mathrm{H}\right]$ leucine incorporation into total protein of untreated normal soleus muscles amounted to 157 (SE 7) $\mathrm{nmol} / \mathrm{g}$ wet weight per $\mathrm{h}$. This should be compared with the value of $140 \mathrm{nmol} / \mathrm{g}$ wet weight per $\mathrm{h}$ obtained by Odessey \& Goldberg (1972) in the isolated rat soleus muscle at $37^{\circ}$ using $\left[{ }^{14} \mathrm{C}\right]$ leucine at a concentration of $0 \cdot 1 \mathrm{mmol} / 1$. The physiological plasma level of leucine is $0.1 \mathrm{mmol} / 1$ in the rat (Banos et al. 1973). Recently, Hood \& Terjung (1987) found in a perfused rat hind-limb muscle preparation that the incorporation 
of $\left[{ }^{14} \mathrm{C}\right]$ leucine into soleus muscle amounted to $102 \mathrm{nmol} / \mathrm{g}$ per $\mathrm{h}$ using a leucine concentration of $0.5 \mathrm{mmol} / 1$ in the perfusate. As shown in Table 1, the incorporation of $\left[{ }^{3} \mathrm{H}\right]$ leucine into protein was about $45 \%$ higher in soleus than in EDL muscle. This is in keeping with the difference observed in measurements of $\left[{ }^{3} \mathrm{H}\right]$ phenylalanine incorporation $(49 \%)$ into protein (Maltin \& Harris, 1985).

Treatment with ouabain decreased the $\mathrm{K}$ content of muscle and a significant correlation could be demonstrated between this variable and $\left[{ }^{3} \mathrm{H}\right]$ leucine incorporation. Incubation of soleus muscles for $180 \mathrm{~min}$ in the presence of ouabain reduced incorporation by $58 \%$. In a similar way, Odessey \& Goldberg (1972) found that incubation with ouabain for $90 \mathrm{~min}$ inhibited the incorporation of labelled leucine into proteins of rat diaphragm by $44 \%$.

It has been shown previously that ouabain can inhibit the transport of certain amino acids into muscle cells. Odessey \& Goldberg (1972) found, however, that leucine oxidation and accumulation into the intracellular pool were not significantly altered by incubation with ouabain. Taken together, these results indicate that the inhibition of $\left[{ }^{3} \mathrm{H}\right]$ leucine incorporation into protein is induced by $\mathrm{K}$ depletion and that protein synthesis depends on $\mathrm{K}$, confirming the observations of Alexis et al. (1971) and Ledbetter \& Lubin (1977).

The influence of $\mathrm{K}$ on protein synthesis is, however, different in the in vitro and in vivo system. Reducing the $\mathrm{K}$ content of muscle in the vitro system by $10 \%$ reduced $\left[{ }^{3} \mathrm{H}\right] l$ leucine incorporation by $7 \%$, whereas a similar reduction in the in vivo system inhibited incorporation by $34 \%$. This much more pronounced inhibition in vivo indicates that other regulatory factors are of importance.

The inhibition of $\left[{ }^{3} \mathrm{H}\right]$ leucine incorporation observed in the in vivo experiments could also be demonstrated in muscles prepared from $\mathrm{K}$-deficient animals ( 1 week on K-deficient fodder) and incubated in Krebs-Ringer bicarbonate buffer with a normal $\mathrm{K}$ content $(5.9 \mathrm{~mm})$. In these mucles, the $\mathrm{K}$ content was reduced by only $10-11 \%$, indicating that the defect in protein synthesis is maintained in spite of almost complete $\mathrm{K}$ repletion. The observation that the defect could only be restored by $\mathrm{K}$ repletion in vivo $(24 \mathrm{~h})$ suggests that the $\mathrm{K}$ content is less important than endocrine factors controlling the overall capacity for protein synthesis. Following a longer $\mathrm{K}$ depletion period ( 2 weeks), the incorporation of $\left[{ }^{3} \mathrm{H}\right]$ leucine into protein in vivo was not even fully restored after $24 \mathrm{~h}$ of $\mathrm{K}$ repletion in vivo (see Fig. 4).

\section{In vivo experiments}

In the $\mathrm{K}$-deficient rats, the incorporation of ${ }^{3} \mathrm{H}$ activity from $\left[{ }^{3} \mathrm{H}\right]$ leucine and $\left[{ }^{3} \mathrm{H}\right]$ phenylalanine into protein was clearly inhibited in all the muscles tested. As shown in Fig. 3 the relative reduction was almost the same in diaphragm, soleus and EDL $2 \mathrm{~h}$ after the injection of $\left[{ }^{3} \mathrm{H}\right]$ leucine. If the inhibition were due to reduced absorption from the peritoneal cavity, more pronounced actions would have been detected in the hind-limb muscles, and no inhibition would have been detected in the experiments with intravenous injection. Furthermore, the incorporation of ${ }^{3} \mathrm{H}$ into the proteins of the heart, liver and plasma was relatively unaffected by $\mathrm{K}$ deficiency. This may be related to the fact that in the heart the $\mathrm{K}$ content was only reduced by $17 \%$ after $14 \mathrm{~d}$ on fodder containing $1 \mathrm{mmol}$ $\mathrm{K} / \mathrm{kg}$. It has been shown previously that the $\mathrm{K}$ content of rat liver is unaffected by 48 weeks of $\mathrm{K}$ depletion (Heppel, 1939; Kjeldsen et al. 1984). In keeping with these observations, the total concentration of proteins in plasma was not reduced by $\mathrm{K}$ depletion. Gustafson et al. (1973) evaluated protein synthesis by the in vivo incorporation of $\left[{ }^{14} \mathrm{C}\right]$ leucine into organs and muscle tissue of $\mathrm{K}$-depleted rats and found only a $21 \%$ decrease in the ${ }^{14} \mathrm{C}$ activity of skeletal muscle protein (not significant). This could be attributed to the fact that the animals used were larger $(200-220 \mathrm{~g})$ and likely to have a slower growth rate and turnover rate of muscle proteins.

The reduced incorporation of $\left[{ }^{3} \mathrm{H}\right]$ leucine into muscle tissue seen in $\mathrm{K}$-depleted animals 
could be due to an impaired Na-gradient-dependent transport of amino acids into the cell. However, acute $\mathrm{K}$ repletion by the administration of $\mathrm{KCl}$ via stomach tube leading to normal muscle $\mathrm{K}$ values (and normal transmembrane Na-gradient) caused no significant increase in leucine incorporation within the first $2 \mathrm{~h}$ and incomplete restoration even after $24 \mathrm{~h}$. Furthermore, the accumulation of $\left[{ }^{14} \mathrm{C}\right] \alpha$-aminoisobutyric acid, which depends on the transmembrane Na-gradient, was not reduced in the muscles and the heart of the $\mathrm{K}$ depleted animals, presumably because the decrease in Na-gradient was not sufficient to bring about any major interference with $\left[{ }^{14} \mathrm{C}\right] \alpha$-aminoisobutyric acid accumulation.

It could be argued that the amount of leucine used in the experiments with intraperitoneal injection would be inadequate to flood the precursor pools to the same extent in the controls and the K-deficient animals. When $\left[{ }^{3} \mathrm{H}\right]$ leucine was given intravenously in a tenfold larger dose, there was the same relative inhibition of the incorporation into muscle proteins in the K-deficient animals. Also the in vitro experiments indicate that the impairment of protein synthesis seen in muscles isolated from $\mathrm{K}$-deficient animals cannot be attributed to reduced availability of precursor.

During sustained $\mathrm{K}$ depletion, the food intake declines (Alexis et al. 1971). This reduction is, however, small during the first week on the $\mathrm{K}$-deficient diet. In further support of this view Rinehart et al. (1967) found that there was no significant difference between the in vivo incorporation of amino acids into muscle protein of control chicks fed ad lib. and those pair-fed to $\mathrm{K}$-depleted chicks. The present experiments showed that control rats given the same amount of fodder as those on $\mathrm{K}$-deficient fodder only had a modest reduction in body-weight and no signficant change in incorporation of $\left[{ }^{3} \mathrm{H}\right]$ leucine into muscle protein.

In young chicks Rinehart et al. (1967) found that the incorporation of $\left[{ }^{14} \mathrm{C}\right]$ leucine into a mixed skeletal muscle sample was significantly reduced when the fodder contained less than $40 \mathrm{mmol} \mathrm{K} / \mathrm{kg}$. However, the $\mathrm{K}$ content in the skeletal muscles was not measured, and inhibition of protein synthesis was attributed to reduced concentration of intracellular $\mathrm{K}$.

Our experiments with graded $\mathrm{K}$ depletion (Fig. 5) indicate that in young rats protein synthesis responds to a similar reduction in the $\mathrm{K}$ content of the fodder. All variables were, however, severely affected when the animals received fodder containing less than $20 \mathrm{mmol} / \mathrm{kg}$. The major new observation is that $\left[{ }^{3} \mathrm{H}\right]$ leucine incorporation is considerably reduced already at modest reductions in cellular $\mathrm{K}$ content.

A clinical implication of suboptimal $\mathrm{K}$ supplies is accentuation of the growth inhibition seen in protein or energy malnutrition (Waterlow, 1984). Cannon et al. (1952) demonstrated that in protein-depleted rats the omission of $\mathrm{K}$ from the repletion diet caused failure to gain weight adequately, and Leach et al. (1959) found that optimum K supplementation gave increased growth at a certain dietary protein content. Thus a diet adequate in $\mathrm{K}$ optimizes the utilization of perhaps already limited supplies of dietary protein.

This study was supported by a grant from DANIDA. The authors would like to thank Tove Lindahl Andersen, Bente Mortensen, Ebba de Neergaard and Marianne StürupJohansen for technical assistance, the Department of Clinical Chemistry, Aarhus Municipal Hospital, for performing plasma protein analyses, and Torben Ellebæk, the Institute of Molecular Biology for performing analyses of plasma leucine.

\section{REFERENCES}

Alexis, S. D., Vilaire, G. \& Young, V. R. (1971). Cell-free studies of protein synthesis with skeletal muscle from normal and potassium-depleted rats. Journal of Nutrition 101, 273-286.

Alleyne, G. A. O. (1970). Studies on total body potassium in malnourished infants. Factors affecting potassium repletion. British Journal of Nutrition 24, 205-212. 
Banos, G., Daniel, P. M., Moorhouse, S. R. \& Pratt, O. E. (1973). The movement of amino acids between blood and skeletal muscle in the rat. Journal of Physiology 235, 459-475.

Cannon, P. R., Frazier, L. E. \& Hughes, R. H. (1952). (1952). Influence of potassium on tissue protein synthesis. Metabolism 1, 49-57.

Chinet, A., Clausen, T. \& Girardier, L. (1977). Microcalorimetric determination of energy expenditure due to active sodium-potassium transport in the soleus muscle and brown adipose tissue of the rat. Journal of Physiology 265, 43-61.

Clausen, T. \& Kohn, P. G. (1977). The effect of insulin on the transport of sodium and potassium in rat soleus muscle. Journal of Physiology 265, 19-42.

Flyvbjerg, A., Dørup, I., Everts, M. E. \& Ørskov, H. (1988). Evidence that potassium deficiency induces growth retardation through reduced somatomedin C production. Pediatric Research 24, 524.

Gustafson, A. B., Shear, L. \& Gabuzda, G. J. (1973). Protein metabolism in vivo in kidney, liver, muscle, and heart of potassium-deficient rats. Journal of Laboratory and Clinical Medicine 82, 287-296.

Heppel, L. A. (1939). The electrolytes of muscle and liver in potassium-depleted rats. American Journal of Physiology 127, 385-392.

Hood, D. A. \& Terjung, R. L. (1987). Leucine metabolism in perfused rat skeletal muscle during contractions. American Journal of Physiology 253, E636-E647.

Kipnis, D. M. \& Parrish, J. E. (1965). Role of $\mathrm{Na}^{+}$and $\mathrm{K}^{+}$on sugar (2-deoxyglucose) and amino acid ( $\alpha$ aminoisobutyric acid) transport in striated muscle. Federation Proceedings 24, 1051-1059.

Kjeldsen, K., Nørgaard, A. \& Clausen, T. (1984). Effect of K-depletion on ${ }^{3} \mathrm{H}$-oubain binding and Na-K-contents in mammalian skeletal muscle. Acta Physiologica Scandinavica 122, 103-117.

Kohn, P. G. \& Clausen, T. (1971). The relationship between the transport of glucose and cations across cell membranes in isolated tissues. Biochimica et Biophysica Acta 225, 277-290.

Kornberg, A. \& Endicott, K. M. (1946). Potassium deficiency in the rat. American Journal of Physiology 145, 291-298.

Leach, R. M., Dam, R., Zeigler, T. R. \& Norris, L. C. (1959). The effect of protein and energy on the potassium requirement of the chick. Journal of Nutrition 68, 89-100.

Ledbetter, M. L. S. \& Lubin, M. (1977). Control of protein synthesis in human fibroblasts by intracellular potassium. Experimental Cell Research 105, 223-236.

Lowry, O. H., Rosebrough, N. J., Farr, A. L. \& Randall, R. J. (1951). Protein measurement with the Folin phenol reagent. Journal of Biological Chemistry 193, 265-275.

McNurlan, M. A., Tomkins, M. A. \& Garlick, D. I. (1979). The effect of starvation on the rate of protein synthesis in rat liver and small intestine. Biochemical Joumal 178, 373-379.

Maltin, C. A. \& Harris, C. I. (1985). Morphological observations and rates of protein synthesis in rat muscles in vitro. Biochemical Journal 232, 927-930.

Odessey, R. \& Goldberg, A. L. (1972). Oxidation of leucine by rat skeletal muscle. American Journal of Physiology 223, 1376-1383.

Rinehart, K. E., Featherston, W. R. \& Rogler, J. C. (1967). Effects of a dietary potassium deficiency on protein synthesis in the young chick. Journal of Nutrition 95, $627 \cdots 632$.

Sapir, D. G., Chambers, N. E. \& Ryan, J. W. (1976). The role of potassium in the control of ammonium excretion during starvation. Metabolism 25, 211-220.

Waterlow, J. C. (1984). Kwashiorkor revisited: the pathogenesis of oedema in kwashiorkor and its significance. Transactions of the Royal Society of Tropical Medicine and Hygiene 78, 436-441.

Young, D. A. B., Clausen, T. \& Balant, L. (1975). Insulin and insulin inhibitor on amino acid transport in rat diaphragm in vivo. Biochimica et Biophysica Acta 389, 194-196. 